\title{
PRINCIPAL LEADERSHIP AND ITS RELATIONSHIP WITH STUDENT LEARNING ACHIEVEMENTS: A REGRESSION ANALYSIS
}

\author{
Ibrahim Bafadal \\ Department of Educational Administration \\ State University of Malang, Indonesia \\ ibrahim.bafadal.fip@um.ac.id \\ Juharyanto \\ Department of Educational Administration \\ State University of Malang, Indonesia \\ juharyanto.fip@um.ac.id
}

\author{
Ahmad Nurabadi \\ Department of Educational Administration \\ State University of Malang, Indonesia \\ ahmad.nurabadi.fip@um.ac.id \\ Imam Gunawan \\ Department of Educational Administration \\ State University of Malang, Indonesia \\ imam.gunawan.fip@um.ac.id
}

\begin{abstract}
Principal leadership is a variable that greatly influences school progress. Therefore, the principal has a duty to improve student learning achievement. This research was carried out with the aim to test the hypothesis: there is a significant influence on leadership learning and spiritual leadership on student learning achievement. The research method used is a quantitative approach. This research was carried out in Malang Raya which covers three regions, namely: Malang City, Batu City, and Malang Regency, in the East Java Province of Indonesia. The sample of this study was a teacher of 181 teachers in 18 schools as a research sample school. The sampling method used was cluster sampling technique, while determining the number of teacher samples using proportional random sampling formula. The data analysis technique used is multiple regression analysis. The results of the data analysis concluded that there was a significant influence of instructional leadership (X1) and spiritual leadership (X2) on student learning achievements (Y). The results of the calculation of the regression equation obtain a formula: $\hat{Y}=191.333+1.997 \mathrm{X} 1$ $+4.632 \times 2$
\end{abstract}

Keywords: instructional leadership, spiritual leadership, student learning achievement

\section{INTRODUCTION}

The highest output from the school is student achievement, which includes the academic and nonacademic achievements achieved by students. Learning achievement is the abilities of a student after he receives treatment from the teacher. Learning achievement is the abilities of students after receiving their learning experience (Sudjana, 2004). Learning achievement is the learning outcomes achieved by students for study in school, both academically and non-academic. Academic achievement is marked with the average national final examination in three years, achievement medal in the Olympics in the last three years, while the achievement non-academic marked by the achievement of champion learners in following festivals and sports competitions and art both at the level of districts, cities, counties, and provinces national and international.

As education leaders, principals have a responsibility to improve student learning achievement. The school principal is the key person who has the task of creating an atmosphere conducive to the growth potential possessed by the students (Adair, 2007; Bezzina, 2000). This means that to produce quality graduates, required principals which teachers move with maximum performance quality (Lima and Passos, 2015; Wong, 2004). Instructional leadership and spiritual leadership applied by the principal become very important in order to support the improvement of student learning achievement. Instructional leadership is the key to the principal to be able to empower teachers to be able to teach maximally. Spiritual leadership is the energy possessed by the principal as an exemplary figure in work, discipline, and full of responsibility.

\section{METHODS}

This research was carried out with a quantitative approach. The variables studied were: instructional leadership (X1) and spiritual leadership (X2) as predictor variables; and student learning achievement $(\mathrm{Y})$ as a criterion variable. The sample of this study is public elementary school teachers in Malang, East Java, Indonesia, which includes Malang City, Batu City, and Malang Regency. The number of research respondents was 181 teachers, spread across 18 elementary schools as research sample schools.

Data collection techniques in this study were using questionnaire techniques, namely an open questionnaire to measure the leadership of the principal, and a closed questionnaire to measure student achievement, in the form of achievement achievements achieved by students over the past three years (Gunawan, 2016a). Research data analysis is multiple regression analysis (Gunawan, 2013; Gunawan, 2016b). Data were analyzed using IBM SPSS Statistics 20.

\section{RESULTS}

The first hypothesis tested is that there is a significant influence of instructional leadership (X1) on student learning achievements (Y). The hypothesis is tested with the $\mathrm{t}$ test coefficient. Regression analysis of instructional leadership (X1) on student learning 
achievements (Y) is shown in Table 1. Based on Table 1 it is known the significance value of $0.047<0.05$ so that $\mathrm{H}_{0}$ is rejected, it can be concluded that there is a significant influence of instructional leadership (X1) on student learning achievements (Y). The leadership learning regression coefficient (X1) on student learning achievements (Y) is 0.182 . The relative contribution of instructional leadership (X1) to student learning achievements ( $\mathrm{Y}$ ) is $3.3 \%$ (from the results of $\mathrm{R}_{\text {Square }}$ calculations $\times 100=0.033 \times 100=3.3 \%$ ).

The second hypothesis tested is that there is a significant influence on spiritual leadership (X2) on student learning achievements (Y). The hypothesis is tested with the t test coefficient. Regression analysis of spiritual leadership (X2) on student learning achievements (Y) is shown in Table 2. Based on Table 2 it is known the significance value of $0.000<0.05$ so that $\mathrm{H}_{0}$ is rejected, it can be concluded that there is a significant influence of spiritual leadership (X2) on student learning achievements (Y). The regression coefficient of spiritual leadership (X2) on student learning achievements (Y) is 0.690. The relative contribution of spiritual leadership (X2) to student learning achievements (Y) is $69 \%$ (from the results of $\mathrm{R}_{\text {Square }}$ calculation x $100=0.690 \times 100=69 \%$ ).

Table 1

Regression Analysis of Instructional Leadership (X1) on Student Learning Achievements (Y)

\begin{tabular}{ccccccc}
\hline $\mathbf{R}$ & R Square & Sum of Squares & df & Mean Squares & t & sig. \\
\hline .182 & .033 & 2175.628 & 1 & 2175.628 & 1.009 & 0.047 \\
\hline
\end{tabular}

Table 2

Regression Analysis of Spiritual Leadership (X2) on Student Learning Achievements (Y)

\begin{tabular}{cccccccc}
\hline $\mathbf{R}$ & R Square & Sum of Squares & df & Mean Squares & t & sig. \\
\hline .831 & .690 & 45421.401 & 1 & 45421.401 & 7.018 & .000 \\
\hline
\end{tabular}

The third hypothesis tested is that there is a significant influence on instructional leadership (X1) and spiritual leadership (X2) on student learning achievements (Y). The hypothesis was tested with the F test coefficient. Regression analysis of instructional leadership (X1) and spiritual leadership (X2) on student learning achievements (Y) is shown in Table 3. Based on Table 3 it is known the significance value of $0.000<0.05$ so that $\mathrm{H}_{0}$ is rejected, it can be concluded there is a significant influence of instructional leadership (X1) and spiritual leadership (X2) on student learning achievements (Y). Regression coefficient of instructional leadership (X1) and spiritual leadership (X2) on student learning achievements (Y) is 0.841. Effective contribution of instructional leadership (X1) and spiritual leadership (X2) to student learning achievements (Y) is $70.8 \%$ (from the results of $\mathrm{R}_{\text {Square }}$ calculations x $100=0.708 \mathrm{x}$ $100=70.8 \%$ ).
Furthermore, based on the results of simultaneous regression analysis, multiple regression equations are calculated from the coefficients ${ }^{\mathrm{a}}$ table as shown in Table 4 . Based on Table 4 it can be seen that the constant value $(\beta 0)$ is 191,333; instructional leadership coefficient value $(\beta 1)$ is 1,997 ; and the coefficient of spiritual leadership $(\beta 2)$ is 4,632 . So the regression equation is: $\hat{\mathrm{Y}}=191.333+1.997 \mathrm{X} 1+$ 4.632X2.

Constants of 191,333 state that if there is no increase in scores from instructional leadership variables (X1) and spiritual leadership (X2), then the score of student learning achievements (Y) is 191,333. The regression coefficient is 1,997 for instructional leadership (X1); and 4,632 for spiritual leadership variables (X2) states that each addition of one instructional leadership score (X1) and spiritual leadership (X2) will give an increase of 1,997 and 4,632 together towards student learning achievements (Y).

Table 3

Regression Analysis of Instructional Leadership (X1) and Spiritual Leadership (X2) on Student Learning Achievements (Y)

\begin{tabular}{ccccccc}
\hline $\mathbf{R}$ & R Square & Sum of Squares & df & Mean Squares & F & sig. \\
\hline .841 & .708 & 46588.466 & 1 & 23294.233 & 18.191 & .000
\end{tabular}

Table 4

Coefficients $^{a}$

\begin{tabular}{|c|c|c|c|c|c|c|}
\hline & \multirow{2}{*}{ Model } & \multicolumn{2}{|c|}{ Unstandardized Coefficients } & \multirow{2}{*}{$\begin{array}{c}\begin{array}{c}\text { Standardized } \\
\text { Coefficients }\end{array} \\
\text { Beta } \\
\end{array}$} & \multirow[t]{2}{*}{$\mathbf{t}$} & \multirow[t]{2}{*}{ Sig. } \\
\hline & & $\mathbf{B}$ & Std. Error & & & \\
\hline \multirow{3}{*}{1} & (Constant) & 191.333 & 97.341 & & 1.966 & .068 \\
\hline & $\mathrm{X} 1$ & 1.997 & 2.092 & .143 & .955 & .355 \\
\hline & $\mathrm{X} 2$ & 4.632 & .787 & .884 & 5.889 & .000 \\
\hline
\end{tabular}




\section{DISCUSSION}

The first conclusion of this study is that there is a significant influence of leadership learning (X1) on student learning achievements (Y). This research is in line with research conducted by Kusmintardjo (2003) which states that instructional leadership has a synergistic relationship and is able to improve student learning achievements. Student learning achievement and the quality of teaching and learning processes that take place in schools are widely dependent on the quality of the principal (Frymier, 1984; Bafadal, 2016a). When schools have good principals, great teachers will attend and work, they work hard, they grow, and ultimately have an impact on the growth of students (Fullan, 2014, Bafadal, 2016b).

The second conclusion of this study is that there is a significant influence of spiritual leadership (X2) on student learning achievements (Y). The findings of this study are in line with the research of Sultoni, et al. (2018) which states that spiritual leadership is able to influence student motivation and learning achievement. The values of spiritual leadership that are able to influence individual students are integrity, honesty, and humility (Reave, 2005). The principal's spiritual leadership becomes a factor that can be adopted by students to learn more diligently. Students will pay attention to the spiritual values displayed by the principal, in addition to the learning behavior displayed by the teacher.

The third conclusion of this study is that there is a significant influence of instructional leadership (X1) and spiritual leadership (X2) on student learning achievements (Y). The findings of this study reinforce the findings of Heck and Hallinger's (2014) study which concluded that if the principal's leadership is applied properly to support teacher's teaching performance, then the goal of improving student achievement would be well achieved. The leadership of learning and spiritual leadership applied by principals can influence the improvement of the quality of school education (Min, et al., 2016). Seriousness of school principals in leading schools affects the learning achievement achieved by their students.

\section{CONCLUSION}

There are three conclusions that can be expressed in this study, namely: (1) there is a significant influence of instructional leadership (X1) on student learning achievements (Y); (2) there is a significant influence of spiritual leadership (X2) on student learning achievements (Y); and (3) there is a significant influence of instructional leadership (X1) and spiritual leadership (X2) on student learning achievements (Y). The findings of this study indicate the importance of the role of school principals as education leaders in schools. The principal is a key person in improving the quality of education in schools.

\section{ACKNOWLEDGMENTS}

Thank you to the Rector of the State University of Malang and the Chair of the Institute for
Research and Community Services, who have funded this research on the research scheme PNBP UM 2018.

\section{REFERENCES}

[1] Adair, J. 2007. Develop Your Leadership Skills. Philadelphia: Kogan Page.

[2] Bafadal, I. 2016a. Strengthening School Governace Through Preparation and Empowerment School Principal As the Instructional Leader. Paper presented in the International Conference the Challenges of Educational Management and Administration in Competitive Environment and the $4^{\text {th }}$ Congress of ISMaPI, State University of Makassar, Makasar, 15-17 April.

[3] Bafadal, I. 2016b. Penilaian Kinerja Kepala Sekolah sebagai Pemimpin Pembelajaran dalam Rangka Peningkatan Akuntabilitas Sekolah. Manajemen Pendidikan, 25(1), 1-9.

[4] Bezzina, C. 2000. Educational Leadership for TwentyFirst Century Malta: Breaking the Bonds of Dependency. International Journal of Educational Management, 14(7), 299-307.

[5] Frymier, J. 1984. One Hundred Good Schools. Indiana: Phi Delta Kappa Publication.

[6] Fullan, M. 2014. The Principal: Three Keys to Maximizing Impact. New York: Jossey Bass.

[7] Gunawan, I. 2013. Statistika untuk Kependidikan Sekolah Dasar. Yogyakarta: Penerbit Ombak.

[8] Gunawan, I. 2016a. Metode Penelitian Kuantitatif. Retrieved June 7, 2017, from http://fip.um.ac.id/wpcontent/uploads/2015/12/2_Metpen-Kuantitatif.pdf.

[9] Gunawan, I. 2016b. Pengantar Statistika Inferensial. Jakarta: Rajawali Pers.

[10] Heck, R. H., and Hallinger, P. 2014. Modeling the Longitudinal Effects of School Leadership on Teaching and Learning. Journal of Educational Administration, 52(5), 653-681.

[11] Kusmintardjo. 2003. Kepemimpinan Pembelajaran Kepala Sekolah dalam Meningkatkan Kinerja Guru: Studi Multikasus pada Dua SMU di Pamalang. Dissertation. Malang: State University of Malang.

[12] Lima, T. F. M., and Passos, T. N. 2015. Evaluating a Learning Management System to Support Classroom Teaching. In Lima, T. F. M., and Passos, T. N. (Eds)., Curriculum Design and Classroom Management: Concepts, Methodologies, Tools, and Applications. New York: IGI Global.

[13] Min, S., Modeste, M. E., Salisbury, J., and Goff, P. T. 2016. Heeding the CALL (Comprehensive Assessment of Leadership for Learning): An Inquiry into Instructional Collaboration Among School Professionals. Journal of Educational Administration, 54(2), 135-151.

[14] Reave, L. 2005. Spiritual Values and Practices Related to Leadership Effectiveness. The Leadership Quarterly, 16(5), 655-687.

[15] Sudjana, N. 2004. Dasar-dasar Proses Belajar Mengajar. Bandung: Sinar Baru Algensido.

[16] Sultoni, Gunawan, I., dan Rosalinda, T. N. 2018. Pengaruh Pembentukan Tim dan Kepemimpinan Spiritual terhadap Motivasi Diri Mahasiswa. JMSP: Jurnal Manajemen dan Supervisi Pendidikan, 2(3), 210-216.

[17] Wong, H. K. 2004. Teachers Teaching and Improving. NASSP Bulletin, 88(638), 41-58. 